\title{
Political exile in the post-2019 Brazilian context: history of exile and work-existence/resistance of a Brazilian intellectual
}

\author{
FERNANDA TARABAL LOPES ${ }^{1}$ \\ Alessandra de SÁ Mello da Costa ${ }^{2}$ \\ ${ }^{1}$ Universidade Federal do Rio Grande do Sul (UFRGS) / Escola de Administração, Porto Alegre - RS, Brazil \\ 2 Pontifícia Universidade Católica do Rio de Janeiro (PUC-RIO) / Escola de Negócios, Rio de Janeiro - RJ, BRaziL
}

\begin{abstract}
Recent years have witnessed the rise of far right-wing leaders in various parts of the world. Stanley (2019) recognizes the particularities of the different nations where this phenomenon is observed but advocates for generalizing it. The author uses the label "fascism" to refer to a variety of ultranationalism. When analyzing the current Brazilian situation, Souza (2019) also refers to fascism, exploring its irrational origins and particularities in Brazil, noticing the emergence of a neo-fascism. Against this backdrop, there are cases of people leaving their countries due to the increasing violence experienced. This study explores this particular situation, presenting the history of Tiburi's exile, a philosopher, writer, university professor, and Brazilian politician. Concerning the theoretical discussion of the case, the study recalls, among other contributions, the debate about the centrality of work and its psychological function and how it presents itself as a form of existence and resistance for political exile. The article also discusses solidarity and the 'public space of word', a possibility that ceases in the country of origin and is sought in expatriation, primarily through work as a mode of existence and resistance. This study uses life history research, which is a rich possibility of apprehending the social experience and the subject in their practices. It is a method particularly fruitful in the study of phenomena such as migration. It is also essential through this research to register and reflect on work in the context of the recent Brazilian political exile.
\end{abstract}

Keywords: Political exile. Fascism. Work. Life histories. Oral sources.

\section{Exilio político no contexto do Brasil pós-2019: história do desterro e do trabalho existência/resistência de uma intelectual brasileira}

\section{Resumo}

Nos anos recentes, vislumbramos em várias partes do mundo a ascensão de líderes de extrema direita. Sobre esse fenômeno, Stanley (2019) nos diz da necessidade de uma compreensão mais generalizada e o descreve sob o prisma do fascismo. Souza (2019), ao discorrer sobre a atual conjuntura do Brasil, também remete às razões irracionais do fascismo e às suas particularidades no contexto brasileiro, chamando a atenção para a emergência de um neofascismo contemporâneo. Dentro desse quadro, observamos a necessidade da saída de pessoas de seu próprio país em função das violências vivenciadas em caráter cada vez mais crescente. Assim, buscamos em nosso estudo, a compreensão desse fenômeno, por meio da apresentação da história do desterro de Marcia Tiburi, filósofa, escritora, professora universitária e política brasileira. Para a discussão teórica do caso, resgatamos, dentre outros aportes, o debate sobre a centralidade do trabalho e sua função psicológica e sobre como o trabalho se apresenta enquanto modo de existência e resistência para o exilado político. Também discorremos a respeito da solidariedade e do espaço público da palavra, possibilidade que se cessa no país de origem e que se busca restaurar no expatriamento, especialmente pela via do trabalho enquanto modo de existência e resistência. Destacamos aqui a metodologia utilizada: a pesquisa em história de vida. Trata-se de uma rica possibilidade de apreensão do vivido social e do sujeito em suas práticas, e que se apresenta especialmente fecunda ao estudo de fenômenos como o da migração. Importa-nos ainda, com o presente trabalho, registrar e refletir acerca do trabalho no contexto do exílio político na história recente do Brasil.

Palavras-chave: Exílio político. Fascismo. Trabalho. Histórias de vida. Fontes orais.

\section{Exilio político en el contexto brasileño pos-2019: historia del destierro y del trabajo existencia/resistencia de una intelectual brasileña}

\section{Resumen}

En los últimos años, hemos visto el surgimiento de líderes de extrema derecha en varias partes del mundo. Acerca de este fenómeno, Stanley (2019) plantea la necesidad de una comprensión más generalizada y lo describe desde la perspectiva del fascismo. Al tratar sobre la actual coyuntura en Brasil, Souza (2019) también se refiere a las razones irracionales del fascismo y sus particularidades en el contexto nacional, llamando la atención sobre el surgimiento de un neofascismo contemporáneo. Dentro de este marco, observamos la necesidad de que personas tengan que salir de su propio país debido a la creciente violencia experimentada. Así, en nuestra investigación, buscamos comprender este fenómeno, presentando la historia del exilio de Marcia Tiburi, filósofa, escritora, profesora universitaria y política brasileña. Para la discusión teórica del caso, rescatamos, entre otras contribuciones, el debate sobre la centralidad del trabajo y su función psicológica y sobre cómo el trabajo se presenta como una forma de existencia y resistencia para el exiliado político. También discurrimos a respecto de la solidaridad y el espacio público de la palabra, una posibilidad que termina en el país de origen y que busca restablecerse en la expatriación, en especial a través del trabajo como una forma de existencia y resistencia. Destacamos aquí la metodología utilizada: investigación de historia de vida. Es una valiosa posibilidad de aprehender la experiencia social y el sujeto en sus prácticas, y es especialmente fértil para el estudio de fenómenos como la migración. También es importante para nosotras, con el presente trabajo, registrar y reflexionar sobre el trabajo en el contexto del exilio político en la historia reciente de Brasil.

Palabras clave: Exilio político. Fascismo. Trabajo. Historias de vida. Fuentes orales. 


\section{INTRODUCTION}

In early 2019, $\mathrm{I}^{1}$ was moving to the city of Rio de Janeiro for the post-doctorate degree. It was then the beginning of the government of Brazil's new President, and the country was in a moment of enormous political turmoil. It drew my attention at that time that some people were leaving the country due to threats and violence directed at them for a long time, but this in the context of the far-right rise to power would undoubtedly become even more problematic and intimidating. This fact moved me deeply; part of Brazil remained in mourning for the presidential inauguration, but for some people, it would no longer be possible to continue to exist in their own country. I could not stop thinking about the pain and violence that permeated a situation like this.

This scenario also reminded me of some of my memories. In the mid-1990s, still in high school, I heard from my History teacher at the time about the period of the military dictatorship in Brazil, and about the characteristics of that time which went back, among other issues, to an alleged communist threat, and the need to fight it through the purge, persecution, and torture of people who represented such fear. Perplexed, I wondered how the citizens managed to believe in such an unreasonable idea, and more than that, to follow and support it through hatred of their fellow man and connivance to this violence. In the learning process of the classes, I was relieved to think that it was a distant past, and with the struggle for the re-democratization of the country, we had reached a clarification that would not allow us to setbacks. I was strongly mistaken.

These are some of the paths and memories that led the authors to the construction of the present research. It is a wide-ranging investigation whose objective is to address the issue of the recent exile of Brazilians from the country appropriating this discussion based on listening to the exiled's account of their history and experiences with the dimension of work as the guiding thread of analysis the dimension of work. Regarding this expatriation, some cases are public and notorious, such as Jean Wyllys (Brazilian politician, journalist and university professor), Debora Diniz (anthropologist, university professor, researcher, essayist and documentary filmmaker), Anderson França (writer, columnist, social entrepreneur) and Marcia Tiburi (writer, university professor, and Brazilian politician); the history of Tiburi's exile is the focus of the present article. Tiburi left the country at the end of 2018, in a condition she called "desterro" (exile). Desterro is understood as any situation of banishment, deportation, exile, and expatriation; the situation triggered in Tiburi's case due to the weight placed on her political, personal, social, and professional life. The account of her history constitutes itself as the central and guiding axis of the article. It is about life-history research.

Life-history research dates back to the beginning of the twentieth-century in the Chicago School (USA), when biographical reports started to gain the status of sociological research material. Among the several possible approaches using biographical methods, Psychosociology stands out as a method in which life-history is considered a valuable research material. It is a rich possibility of apprehending the subject's social experience and practices, observing how they negotiate the social conditions that help build their world. In this world, the subject is building itself simultaneously. It is a methodology, especially fruitful in the study of phenomena such as migration, social mobility, work, and professional history (Barros \& Lopes, 2014). Life-history consists of searching for knowledge from the subject's experience (Barros \& Silva, 2002). It is a way of putting the individual back into the social context and history. Inserted between individual psychological analysis and the analysis of socio-cultural systems, life-history allows understanding how individuals make history and shape their society while being shaped by it (Laville \& Dionne, 1999).

The theoretical-methodological section of the article discusses in greater detail about this type of investigation, in addition to locating it in the field of Management as a possibility for historical research, especially for its ability to problematize historical versions considered as official, also to the emphasis on orality and its critical potential for listening and reporting what tends to be silenced or put aside, such as individual experiences associated with suffering, trauma and political persecution (Ferreira \& Serres, 2018).

Reporting Tiburi's history, in an adequately contextualized form, required other incursions into the field that occurred before listening to her narrative. Thus, I went through courses, lectures, observations, readings, besides our own experiences in a conjuncture of the country that has been characterized by a contemporary neo-fascism. Another vital path is the accomplishment

\footnotetext{
${ }^{1}$ The first-person narration excerpts refer to the experiences and memories of the first author of the present article.
} 
of part of the post-doctorate degree in Paris, France, an experience that allowed the interviews to be carried out in person and during the period of exile, which the authors considered a uniquely valuable and original immersion in the field.

The literature recalled for the construction of the article is divided into two axes. The first one encompasses the context and exile. The discussion about context concerns the current totalitarian situation and its specificities in Brazil (Souza, 2019; Stanley, 2019; Tiburi, 2018). In the debate on political exile, it was considered: 1) perspectives that address political exile that occurred during the Brazilian military dictatorship (Marques, 2011, 2017; Roniger, 2010); 2) the more specific discussion about the political exile of Brazilians in the post-2019 context (Pinheiro-Machado, 2019; Villen, 2018); besides, 3) an explanation about the subjective dimension of exile (Indursky \& Conte, 2015).

The second theoretical axis deals with work, its centrality, psychological function, mode of existence and resistance in political exile, and it was supported by references learned from the psychoanalytic field (Freud, 1910, 1914, 1930), and the field of Psychodynamics of Work (Dejours, 1996, 2008), among other contributions. Regarding this axis, it is necessary to point out that it was built during and after immersion in the field (which I highlight: the fieldwork of collecting Tiburi's history); it was the fieldwork that guided the authors towards the resumption of this theoretical-analytical lens. It is a central epistemological direction for working with life-history. Thus, a positioning stands out according to a reflective perspective on the knowledgeknowledge that is not given a priori but built throughout the investigation process (González Rey, 2005). Besides, the intention of this sort of research construction is also reinforced in the sense of highlighting the person's history as it seeks to understand the person's perspective on themself and social facts based on their capacity for analysis. This point was crucial to the present investigation; Tiburi shared her experience, and elucidated and instigated several analytical, theoretical and philosophical considerations on the subject.

The article's final thoughts resume the discussion about the fascism context focusing on what is possible to reflect on this condition from the history of Tiburi's exile. Likewise, it highlights the contributions on the political expatriation issue, dimension of work and its contributions to the organizational field. Ultimately, this study emphasizes the need for a research agenda to be considered in future works on the theme.

\section{DESPOTIC CONJUNCTURE}

The recent years witnessed the rise of far-right leaders in various parts of the world, each with their particularities. Although recognizing the particularities of the different countries, Stanley $(2019$, p. 14, our translation) argues that this phenomenon needs to be generalized, using a broader understanding of fascism. In his words: "I have chosen the label 'fascism' for any type of ultranationalism [...] with the nation represented in the person of an authoritarian leader who speaks on its behalf. As Donald Trump stated in his Republican Convention speech in July 2016, 'I am your voice."'

Souza (2019) described the Brazilian context in 2018 and early 2019, also referring to fascism. The author explores the irrational origins of the concept and focuses his analysis on the national elections held during the period, which were marked by fake news and accusations of illegal campaign financing. Souza (2019, p. 250, our translation) raises the question: "what explains the fact that the majority of our society, under the pretext of preventing the arrival of a supposed 'thief' to the presidency, voted for a candidate who advocates murder and torture of opponents?" Acknowledging the complexity of the phenomenon addressed by the author, which resumes the historical genesis of Brazilian colonization, and the period of slavery and domination, this article highlights fascism in modern Brazil. It is a more comprehensive type of fascism than historically linked to a manifestation of the middle class, which integrates parts of the low-income population. On this point, Souza (2019) emphasizes that:

All fascism is, therefore, a reflection of a truncated class struggle. It is perceived in a distorted way, which makes it violent and irrational at its core. It is based on the manipulation of emotions leading to aggressiveness, such as fear, anger, resentment, and anxiety, without direction, and for political manipulation. The population's rational misunderstanding of complex political processes is used to build scapegoats, a historically efficient way of channeling social frustrations and resentments. The marginalization of minority groups and covert violence, contaminating society as a whole, are the inevitable consequences of all fascism (Souza, 2019, p. 252, our translation) 
Souza (2019) advocates the urgency of understanding the context of fascism today, calling it the "contemporary neo-fascism." He argues that the present phenomenon brings up the same fascist policy strategies already experienced in the past, but adapted with specific features typical of the current conjuncture: cult to the patriarchal tradition and mythical past, anti-intellectualism, unreality, hierarchy, appeal to the notion of homeland, and disarticulation of the union and public welfare (Stanley, 2019). Fascism also refers directly to the most radical authoritarianism, where dialogue and collective participation are unthinkable outside what interests those in power. Hatred founds and shapes authoritarianism - hatred of the other, hatred of politics: "the genocide of indigenous peoples, the racist and classist massacre against young black people and the poor on the outskirts of big cities, domestic violence and the murder of women, homophobia, the manipulation of children, in simple words, hatred of the other grows in a society where the extermination of politics is also at stake" (Tiburi, 2018, p. 29, our translation).

In Brazil's specific case, the arise of a context of urgency for some people to leave their own country due to violence experienced by them emerges as the existence of exile in post-2019 Brazil.

\section{“BRAZIL, LOVE IT OR LEAVE IT"2}

Due to economic issues, Brazil has already been a country with a considerable migration index for some years with numbers that have tripled, especially in 2017 and 2018, due to as a result of the crisis observed in that period. Pinheiro-Machado (2019), referring to data from the Internal Revenue Service conceded to The Intercept (news agency), describes that the number of immigrants in these years has tripled when compared to previous years: for instance, in 2011 the number of people which declared the final exit was 8170; in 2017 and 2018, about twenty-two thousand people (Pinheiro-Machado, 2019). In addition to the economic scenario, migrants are leaving Brazil now that political issues are coupled with the rise of the far-right in the country. It is a forced uprooting of people who then seek shelter in other countries due to political persecution and the consequent associated violence.

Pinheiro-Machado (2019) points to a recent 'brain drain' from Brazil and refers to intellectuals who have been persecuted as indoctrinators. "Following the fascist logic, we are faced with unprecedented stigmatization of academic knowledge in Brazil that turns the scientist into the internal enemy to be destroyed. For those who do not have stability in Brazil - and even for those who do - only the forced escape route remains" (Pinheiro-Machado, 2019, our translation). In such a scenario, the author warns the return of a Brazilian political exile and the generalization of fear that occurs among academicians, activists and intellectuals who are targets of psychological terror and under life threats. "We are returning to the acute situation of exile. We will have an increasing number of people seeking protection abroad. The best-known cases are those of former deputy Jean Wyllys, anthropologist and law professor Debora Diniz, and the philosopher Márcia Tiburi. They live abroad because their lives are threatened by far-right groups" (Pinheiro-Machado, 2019, our translation).

The Guardian newspaper refers to the "new generation of political exiles leave Bolsonaro's Brazil 'to stay alive'". In addition to the aforementioned people, the newspaper adds the case of Anderson França (writer, columnist, social entrepreneur) and comments: "the four exiles all describe a cocktail of threats from paramilitary gangs, rightwing extremists and a nihilistic dark-web forum whose users spew hate for leftists, women and black people". The four cases mentioned referring to people who made public their departure from Brazil by cause of the far-right rise in the country's recent history.

Villen (2018), allude to the current production of Brazilian political refugees that begins to become the rule from the present despotic, authoritarian and persecutory mode that is installed against:

the various forms of status quo reaction and criticism that mainly affect the leaders of social movements (as shown by the aberrant murder case of Rio de Janeiro's councilwoman Marielle Franco and many other militants) but also teachers and students. Many of these government techniques were already used during the dictatorial period and return from the "ashes" to impose a conservative, anti-democratic order in different dimensions - political, economic, cultural, and religious (Villen, 2018, our translation).

\footnotetext{
${ }^{2}$ Slogan phrase from the period of Brazilian military dictatorship that was recently replicated by the commercial television channel SBT- Brazilian Television System (Folha de São Paulo, 2018).
} 
For the reason that these people are fleeing, and since the theme of this article is hugely contemporary, it is difficult to mention precisely the number of people who are leaving Brazil at this time for reasons related to political persecution. During a conversation with Marques about the topic, a specialist in political exile, the researcher emphasized this difficulty, even concerning the political exile of the period of the Brazilian military dictatorship. Providing a more accurate picture of this fact, the researcher found numbers of exiled people from that time fluctuating between 1,000 to 10,000 (a considerable variation, inaccurate and difficult to define) amid her doctoral thesis investigation (Marques, 2011). Such difficulties are related to the very nature of political exile, among other issues.

The political exile in Brazil was strongly present during the dictatorial period that began in 1964. In the course of a study carried out relative to the exiled people of that time, Marques (2017), explores the phenomenon demonstrating how it becomes characteristic of regions in which the institutions are marked by political instability accentuating itself as a mechanism of selective punishment and exclusion. Roninger (2010), also addresses the topic and mention the massive exile process in Latin America in the twentieth century highlighting how this was configured as a parallel mechanism of political exclusion and preferable than the incarceration or burial, once the latter options were generally intended for people from the lower classes. The author calls attention to how the exile is structured as a political procedure that allows the control of the public sphere at lower costs and consequences for the current autocratic power, thus, shaping itself as an institutionalized exclusion mechanism favorable to the hierarchical structures' perpetuation.

In addition to the comprehension through the political sphere, it is necessary to observe the subjective dimensions of the exile condition. Going into exile surpasses the notion of "a geographical distance and the impossibility of returning to the homeland, it refers to a specific psychic process of uprooting identity" (Indursky \& Conte, 2015, p. 274, our translation). These authors notice the semantic polysemy of the word exile, specifically its derivation from the French language. Thus, the spelling exil, when decomposed (ex-il), refers to "ex-he" (in English), which precisely denotes the idea of losing the identity as a consequence of leaving the country of origin. They add:

The geopolitical break-up situation and the impossibility of returning to the motherland reveal, therefore, the psychic condition of the subject in exile from themselves, who is located in a space-time hiatus. In other words, the subject is neither here nor there, neither now nor once but he/she is in inter-worlds. The subjective uprooting that underlies this condition has a direct impact on the possibility of symbolic and identity affiliation in view of the new host country. This paradox is highlighted by the graphic line between the subject and their former identity (ex-il): if, on the one hand, we observe the sign of separation from everything that allows the individual to recognize themself as the subject of desire; on the other hand, we observe their irremediable belonging to such signifiers and objects, as a privileged form of symbolic/imaginary evocation of their affiliation. As Janine Altounian (2005) suggests, the exiled subject must put themself to the test of elaborating and translating the marks of such transitions in order to reinscribe their memories in another spatiality, thus transmitting their cultural heritage (Indursky \& Conte, 2015, p. 277, our translation).

Such explanations express characteristics, vicissitudes of exile and the importance of its comprehension in a broad and interdisciplinary mode. Although the occurrence of exile itself may not necessarily lead to a traumatic or pathological experience, indeed, the very fact of being under the exile condition will demand from the subject an exigent process of psychic elaboration. The absence of cultural mediators, spatial-temporal demarcations of social writing of their paths, and stories are some of the issues that mark this path (Indursky \& Conte, 2015).

\section{HISTORICAL RESEARCH IN MANAGEMENT}

Since the late 1980s, research in the area of Management has increasingly incorporated and legitimized interdisciplinarity. The dialogue established with other areas of knowledge, such as, for example, psychology, sociology, and anthropology, contributes to the understanding and analysis of the phenomena in Management through a more comprehensive and multifaceted perspective. This is also the case for areas of knowledge, such as history and memory studies, which deal with the past and its representations. As a result, there have been several epistemological discussions about how to know and access the past (Decker, Hassard \& Rowlinson, 2020; Godfrey, Hassard, O'Connor, Rowlinson \& Ruef, 2016; Wanderley \& Barros, 2018; Wadhwani, Suddaby, Mordhorst \& Popp, 2018) and methodological discussions on how to use the written and oral historical sources in management research (Lubinski, 2018; Schultz \& Hernes, 2013). 
The use of oral sources gains relevance because they allow to complement, relativize, and problematize versions of history, based only on official written documents. In this sense, as an alternative to written sources, orality allows critical and reflective thinking about winning pasts. Say the unspeakable. In other words, the different ways of narrating individual histories (life stories, biographies, and autobiographies) allow the researcher (and society) to listen to what was previously silenced and put aside, as individual experiences associated with suffering, trauma, and political attacks (Ferreira \& Serres, 2018).

\section{Life-history research}

"We tell stories because, in the end, human lives need and deserve to be told" (Ricoeur, 1983, our translation).

Life-history research emerged based on the tradition of the Chicago School (empiricist sociology), a time when the method became relevant for sociological analyzes, as it allows direct contact with people's "experiences", with the fundamental "raw material" of social research (Ferraroti, 2007, p. 16). Such research leads to a variety of possibilities for guidance and management, according to the different fields of study involved in the endeavor. This research is based on the perspective of Psychosociology, an area that values, among other guidelines, the reciprocities between the individual and the collective, between the psychic and the social.

"Histaur," from Greek, represents 'the one who knows and therefore can report.' It means to reflect on an experience, in the dialectic between material reality and subjective reality. According to Ferraroti (2007), life stories consist of a dialectical intertwining between the individual, culture, and the moment (or historical phase), which means, apprehending the nexus between text, context, and inter-text. Regarding this connection, the author also highlights that this relationship defines the individual as part of a living process, at the same time as a historical agent. The author reinforces the importance of life stories for their ability to express the daily life of formal and informal social structures - a fundamental contribution to social research.

It is essential to highlight that far from focusing exclusively on the individuality, understanding one's life history is always a return to the collective and its respective historicity. A fundamental element for researching stories is to create a "bridge" between individual and collective history, outlining what can be named a 'cartography of the individual history' in search of its collective seats.

About the use of life-history, Arfuch (2010) exposes the concern on the analysis methodology, reinforcing that the analytical and reconstruction paths of a story start from the story itself, which must be preserved in its entirety and context. Bosi (2003) confirms this consideration stating that "the freedom of a testimonial must be respected at any price. It is a serious problem in research ethics. If memory is not passivity, but a form of organizing, it is important to respect the paths that those who remember are opening when they speak, because these paths are the affective map of their experience and the experience of their group" (Bosi, 2003, pp. 55-56, our translation).

Although our previous examples show an agreement with this dialogical position, sensitive to nuances, aware of the functioning of language and narration, and willing to recognize its leading role to the other, we do not consider that, even within these parameters, there is a privileged analysis methodology. As with other genres and discourses, the type of text material, the corpus built, and the goal to be achieved impose - or suggest - the form and paths of analysis. What may be possible to establish, a priori, is what should not be done when using the life stories produced based on in interviews: to assume, without precautions, having the privilege of flattening, reducing, eliminating, glossing, cutting the word. Although every time one uses a quote, a fragment of the statement to portray some information - and considering that every interpretation is arbitrary - there are degrees of manipulation (Arfuch, 2010, p. 267, our translation).

Another important element of the method is the influence of the relationship between researchers and those who tell their stories. For Ferraroti (2007), there must be a significant relationship, an authentic and trusting interaction; at this level, the research does not present a typical asymmetric structure, which reflects power relations. The author adds that the researcher and the researched must also be engaged, which includes the researcher's commitment to looking at their own life story; the "life stories help to understand that in social studies, every researcher is also researched" (Ferraroti, 2007, p. 17, 
our translation). Arfuch adds that the other is not merely a "case," or a "source" (of information). They must be considered as an "interlocutor" (Arfuch, 2010).

Regarding the implementation of the life-history research method, Bosi (2003) argues that the ideal interview allows bonds of trust to form: "we must always remember that the relationship should not be ephemeral. It involves responsibility for the other and must last as long as a friendship lasts. The quality of the interview will depend on the quality of the bond. If it was not, the interview would have something similar to the phenomenon of surplus-value, an undue appropriation of the time and breath of the other" (Bosi, 2003, p. 60, our translation).

Another characteristic attributed to the method is its "therapeutic nature." After all, why does one narrate their life? As Chauí (1973) points out, "remembering is not reviving; it is re-doing." In general, telling the story of life is always about bringing back something impossible, but in a way that gives it meaning and permanence; it corresponds to a way of structuring life, i.e., structuring identity. In this narrative, "the memory no longer has a character of restoration. It becomes the memory that creates the future. As put by Merleau-Ponty, the time of remembrance is not the past, but the future of the past" (Bosi, 2003, pp. 66-67, our translation).

Regarding the relevance of life-history research for the understanding of political exiles, Barros and Lopes (2014) observe that:

Some contexts are particularly fertile when studied through life stories, such as movements and social changes, the phenomena of migration, social mobility, marginalization and exclusion, the repercussions of economic and social crises, the emergence of certain forms of individualism, solidarity, sociability, resistance, and power, as well as work and professional history. The interest in these stories stems especially from the easy access they offer to representations and observation of how people live in society, in addition to the ability to provide hypotheses for more general explanations (Barros \& Lopes, 2014, pp. 50-51, our translation)

It is essential to highlight that in life-history research, as a biographical approach, the person who tells the history has a central role. They present the raw material on which the study is developed, and reality or the events are known based on their comprehension about life. Thus, the researcher has the possibility of delving into dimensions that are difficult to apprehend outside the subjects' stories, getting to details that might go unnoticed if using other methods. The method helps to improve the research and enhance the investigation, as well as helping to overcome the limits of official stories (Barros \& Lopes, 2014).

Life-history research is related to what Habermas (2009) defines as an experience of reflection, which refers to the dialectic between the knowledge of the world and self-knowledge. The experience of reflection is a process that only occurs through the subject's reflection on themself: "[...] the subject also needs to tell their own history; because the final state of a formation process is not reached before the subject remembers the paths of identification and alienations in which he/she was constituted". Therefore, according to Habermas, an investigation is based on the science perspective that does not aim at general theories in the sense of rigorous experimental sciences but rather at a general interpretative sense (such as Psychology), which aims at reflection and clarification concerning the formation process itself: an emancipatory cognitive interest.

In this research, besides collecting Tiburi's history, other incursions in the field were done. As Ecléa Bosi warns, "before meeting with the interviewee, it is advisable to collect as much information about the issue in question to formulate questions that encourage them to answer. It can be a consultation of publications: newspapers, magazines, songs, books, anecdotal images, anyway, everything that will make the narrator vibrates at the time we want to study" (Bosi, 2003, p. 59). Thus, during the period in Rio de Janeiro city and specific visits in the city of São Paulo, the authors of this research went through courses, for instance, "Mutações. ainda sob a tempestade. Ciclo de palestras sobre o fascismo" (Mutations. Still under the storm. Lectures series on fascism), by intellectuals such as Vladimir Safatle, Maria Rita Kehl, Renato Janine Ribeiro, also "Psicologias do Fascismo" (Psychologies of Fascism), by Vladimir Safatle held in the Philosophy Department of USP-University of São Paulo, among others; lectures, for example, "A Crise da palavra. outros modos de ser Brasil - ou Brasis" (The word crises. other forms 'to be Brazil - or Brazils'), by Eliane Brum, "Constelações insurgentes: fim do mundo e outros mundos possiveis" (Insurgent constellations: the end of the world and other possible worlds), by Ailton Krenak and Suely Rolnik, among others; notes, some of them originated from, e.g., the attendance of the "Fórum da Resistência Democrática" (Democratic Resistance Forum); readings, including oeuvres, videos, and information in digital media produced by the exiled themselves regarding their conditions; in addition to the authors' own experiences in Brazil. 
There was also an opportunity to reflect on exile and Brazil's current situation during the split-site doctoral program in France. The journey in French territory was shaped amid participations in the following seminars: "Actualité de la pensée politique au Brésil et dans le monde. Dialectique négative comme strategie d'émergence" (Current political thought in Brazil and in the world. Negative dialectic as an emergency strategy), by Vladimir Safatle, "Séminaire de recherche. UFR11- Science Politique. CRPS/CESSP. Université Paris 1 - Panthéon Sorbonne" (Research seminar. UFR11 - Political Science. CRPS/CESSP. Paris 1 University - Panthéon Sorbonne), by Teresa Cristina Schneider Marques, and "Séminaire sur les mutations en cours au Brésil et dans le monde" (Seminar regarding the changes underway in Brazil and in the world), by Rosana Pinheiro-Machado and Plinio Prado Junior.

\title{
MARCIA TIBURI'S HISTORY
}

\author{
"Go, my brother, \\ Take this plane \\ You are right \\ To run like that from the cold" \\ (Buarque \& Toquinho, 1971, \\ our translation).
}

The first meeting of the researcher (this article's lead author) with Marcia Tiburi took place in January 2020, in Paris (France), during her exile. An appointment for a previous conversation was made after a few email exchanges. At that point, Tiburi was already in exile for about one year after leaving Brazil due to a series of violence and threats intensified in 2018.

Marcia Tiburi is Brazilian, born in Vacaria, in the state of Rio Grande do Sul, from a family of Italian immigrants who came to Brazil in the first half of the twentieth century. Tiburi is a philosopher with a degree obtained when she was 20 years old. She obtained a master's degree at the age of 23 and a Ph.D. before she was 30. Tiburi also holds a degree in arts and has worked from a very early age as a university professor. From a young age, Tiburi understood the importance of making philosophy accessible and intelligible to people in general. She wanted to promote concrete and real dialogue with society through philosophy. Marcia Tiburi mentioned that the involvement with the public sphere was possible to be in touch with the world and talk about philosophy.

In the early 2000s, Tiburi had a strong presence in the mass media (she participated in the television program "Saia Justa," shown by the Brazilian television channel GNT). She said the participation in the program was a form of occupying and living with this type of communication mean in a dignified manner and with a critical eye. Tiburi also said to have used social media in a considerable measure, pointing out that she had reflected on such platforms and considers that people should thoroughly think about how to use them. She mentioned facing these platforms with care and observing the extent to which the individual's relationship with social media may damage the integrity of the person's relationship with life.

Regarding her formal participation in political life, she explained she joined a political party - her first affiliation was with the Partido Socialismo e Liberdade (PSOL) (Socialism and Liberty Party), at the end of 2013 - after much study. Her participation in the cause of feminism occurred with similar care. She reported not being a person who originally came from these places, "neither from family, nor from society, nor culture." She mentioned not having a history related to political parties, nor a tradition participating in social struggles. She mentioned having come from that social class "the most accommodated, massacred, and at the same time, the most silent." However, her studies led her to reflect on the importance and need for a more autonomous society.

In 2017, she left PSOL; at the time, she was against some of the party's stances such as the defense of "Operation Car-Wash," the support in producing a movement against the Partido dos Trabalhadores (PT) (Workers' Party), which culminated in a disinformation campaign. After one year of leaving PSOL, Tiburi joined the Workers' Party (PT). In her words: "in a somersault, at the moment when PT was being massacred, early 2018, Lula ${ }^{3}$ was about to be arrested, Marielle ${ }^{4}$ was murdered. I went to PT because I realized we were sinking, so I decided to seek the opposite direction." In the Brazilian national elections of 2018, she was PT's candidate running for the state government of Rio de Janeiro.

\footnotetext{
${ }^{3}$ Luiz Inácio Lula da Silva, or "Lula”, was the 35th Brazilian President for the period from 2003 to 2010.

${ }^{4}$ Marielle Franco was elected member of the City Council in Rio de Janeiro for a mandate from 2017 to 2020. On March 14, 2018 , she was murdered.
} 


\section{Attacks, violence, and attempts of slander}

Marcia Tiburi said that, even when she participated in the TV program, she was already attacked by people reflecting a far right-wing thought. For example, she mentioned the attacks suffered in 2011 by Olavo de Carvalho ${ }^{5}$. She reported that, at that time, she acted as if nothing was happening; she thought: "annoying people, ignorant people, and people who were looking for a catapult to appear" (at this moment, she refers to a practice in which figures not publicly known use the notoriety of others, through defamation, to self-promote).

Tiburi discussed the attacks suffered in consequence of her book "Como conversar com um fascista" 6 (How to talk to a fascist), a work that suffered intense attacks from the far right-wing groups. In 2017, she was targeted with retaliation for having used the word "cú" ("asshole") in the launch of the book "Ridículo Político,"7 (Ridiculous politics) in the city of Belo Horizonte. The retaliations occurred in the form of misinformation and fake news constructed to slander, using strategies such as grotesque images, unspoken phrases and/or clipped from their contexts.

Tiburi told about an event that happened in January 2018, in Porto Alegre. She was in the city and was invited to follow and comment on Lula's trial at the Brazilian Federal Regional Court, during the broadcast of Rádio Guaíba, a local radio station. Tiburi told that, at that time, she was launching the book, "Feminismo em comum"8 (Feminism in common), and the invitation to be on the radio also concerned a presentation of that work. According to her:

That day, I starting to talk to him (the radio presenter), I did not even notice that there is something in the air [...] we were there talking, talking without much concern, and suddenly the door opens and a person passes by me, kisses me on the cheek. [...] Well, when he sits in front of me, that is when I realize that he is Kim Kataguiri, who was the leader, the MBL's ${ }^{9}$ guru. And then I get scared because evidently, I knew these guys were starting a political campaign, even when it was not the period for political campaigns. They adopted the same tactic of using a public figure to create controversy with that person [...] and then attracted the attention for themselves. And, at that time, I still had not formulated this comprehension, but I had the feeling of falling into a trap, sabotage, an ambush. I realized that this was a heavy media ambush. I was so scared, I wasn't expecting it, I said absurd things ... I left very scared saying things [...], and I left (Tiburi, our translation).

This event was disseminated on social media with the purpose of, according to Tiburi, depreciating her and promoting the opposition groups. In this episode, she received support from many people, but also hatred from others. Her book "Como conversar com um fascista" (which recently had a new edition produced) was challenged based on the event.

Marcia Tiburi mentioned that the attacks and slander also occurred at the university. She commented that a university professor verbally attacked her in the classroom. "He referred to me as 'this woman' ... a typical misogynistic attitude. The guy said things like 'when I enter the bookstore, I take that book, and I hide it'" (about her book). Tiburi considers that fascism also grows in universities, and reflects on the pseudo-left-wing in the academic environment: "how to survive fascism if these people, who should be decent, do this kind of thing? He spoke like that; he called me a popcorn maker, he said that I sold popcorn."

Another episode of harassment and depreciation was when they took a snippet of a 2015 speech, in which she mentioned that a coup was already under construction. In this case, she commented on the issue of robbery, building an argument during her speech to a point when she said: "for example, I can say that I am in favor of the robbery." The phrase was then used by slanderers, in a strongly decontextualized way; she reported that hundreds of memes, videos, and messages of disinformation were produced. According to her, some people still call her someone that 'defends robbery.' The MBL put a picture of her on its website with the label: "Wanted." She mentioned that a "horde' of "young people lost, with no future, who are being mobilized by the far-right" were encouraged to participate in the events she was participating in, harassing and terrorizing her. She gave the example of an episode in Belo Horizonte, during one of her novel launches in 2018. She reported that an armed man appeared, carrying a gun in a plastic bag. After noticing the presence of this

\footnotetext{
${ }^{5}$ Brazilian essayist, public figure, representative of the conservatism in Brazil.

${ }^{6}$ Tiburi, M. (2018). Como conversar com um fascista. Reflexões sobre o cotidiano autoritário brasileiro. Rio de Janeiro, RJ: Record.

${ }^{7}$ Tiburi, M. (2017). Ridículo Político. Uma investigação sobre o risível, a manipulação da imagem e o esteticamente correto. Rio de Janeiro, RJ: Record.

${ }^{8}$ Tiburi, M. (2018). Feminismo em comum: para todas, todes e todos (6a ed.). Rio de Janeiro, RJ: Rosa dos Tempos.

${ }^{9}$ Movimento Brasil Livre (Free Brazil Movement).
} 
person, people called the police, but he fled. She also reports that, in almost all events related to the book "Feminismo em comum," wherever she went, someone was there to terrorize. In Mato Grosso do Sul, "they beat up people and left them bleeding" (Tiburi, our translation).

In 2015, she mentioned the attacks suffered because of her defense in favor of legalizing abortion. At the time, she was fired from the university where she worked because of her position, even though she was a highly productive professor and had been linked to the institution for 8 years.

At the end of 2018, Tiburi released a nove ${ }^{10}$ and was invited to participate in a festival in Maringá, a city in the Brazilian state of Paraná. A few days before she went to that event, MBL created a website with the words: "ela não" ("not her") and started a strong campaign against her participation.

They said: 'we are going to finish with these PT supporters who come here' [...].

Security measures were so heavy... And I was already under protection for the entire year: bodyguards in bookstores, bodyguards in the mall, bodyguards to leave the house, to return home, bodyguards... I had already been under very heavy security during the campaign, armored car, and everything you can imagine [...] And then, this time it was very heavy, because that there was a security search... I'm not sure if there were 400 or 500 people, but it was an hour and a half of searching. The event was delayed by an hour and a half because of this security search. Then I was sitting there, it was a conversation ... a journalist who had read my book was interviewing me. And then I talked, we kept talking... And then, all the time I was there talking to this journalist, I was afraid of being shot, or that he would be shot... and then I started to be afraid that people around me could be shot... afraid that a madman would arrive as they do in the United States and kill a lot of people. Then I thought: this is not life, neither for me nor for these people.

$[\ldots]$

Then that day I had no doubt that I had to leave the country, I was in an autograph session ... but with a bodyguard with a rifle by my side, all the time. And then I thought: you can't be a writer in Brazil, this is a scam, it is a scam. You can't be a writer in Brazil with this kind of situation, what is this? Then I thought, the best thing I could do for myself and for those people who like me, was to get out of here. So that's why I left (Tiburi, our translation).

\section{ABOUT EXILE AND WORK - “I THINK THIS COUNTRY HAS NO PLACE FOR ME ANYMORE”}

The exile occurred in late 2018. At that time, she was welcomed by an institution in the United States that protects writers from all over the world, attacked and harassed globally, or in their countries. She commented that citizens from the US survive the authoritarian regime (currently in office in that country) through solidarity, which, in her opinion, does not occur in Brazil:

We are in crisis, our solidarity, our generosity, at this moment - not only at this moment, but it has happened for a long time, - is failing. And this is also one of the aspects that will lead Brazil to an even deeper collapse of its democracy. Because to have democracy, we have to have solidarity, we need to have a sense of community and value the community as a whole. And I think that it doesn't happen today ... That's why fascism grows, the ground for fascism to grow and appear is very well plowed, it's very fertile (Tiburi, our translation).

So I went to the United States, first because of this institution (which receives writers living under threat), I got there I was alone in the snow for months, with no family, no one... and I didn't want to tell everyone I had left Brazil because I didn't know how this news would be received... in the meantime, I was organizing myself to stay in the United States, but my husband decided to do a post-doctorate here (in France). [...] Then I decided to come too and received an invitation from a university here,

\footnotetext{
${ }^{10}$ Tiburi, M. (2018). Sob os pés, meu corpo inteiro. Rio de Janeiro, RJ: Record.
} 
Paris 8 , and I came here. And today I have a contract as a visiting professor at this university. Then in Brazil they started, the far-right again, lying about my husband, about me, these are bad people, saying: "oh, Marcia [...] living with government's money, with our money, people paying for your vacation in Paris." They have no idea that my money comes from the French government (Tiburi, our translation).

Upon leaving Brazil and being welcomed in the US university, people asked Tiburi for material to build a dossier about what lead her to the exile condition. Then, she revisited the facts, with the help of friends and alumni; she reported that she was in shock when she received the material. She reported on the difficulty and how it was frightening to see and deal with all that, to have to show and explain to people what had happened. Tiburi reflected on the purpose of the violence directed at her: to destroy her image so that she becomes a powerless person. She commented: "if you kill yourself, if you get depressed, if you give up fighting - they score, then they won."

She recalls her family's immigration status and says she feels used to dealing with the abandonment. About her last novels, which in general deal with the issue of immigration, she commented:

This issue of abandonment, this issue of immigration, this issue of loss of the country ... this is in my father's family and ... and I reproduce it, I work with it in these novels, but I never thought that it could reach me in this political way. I mean, this abandonment experienced by my ancestors, my Italian ancestors, is political ... in a thousand indirect ways, they come to me, they build me in some sense, but I never thought that this could happen to me in such a direct way (Tiburi, our translation).

[...] because my three novels were... from 2012, that I tell the history, I work with the immigration aspect of my father's family, that I bring questions there... it is a novel about the condition of the person in exile. The 2016 novel called "Uma fuga perfeita é sem volta"11 (A perfect escape has no return), which was widely read by several psychoanalysts, this novel too ... it is about a person that leaves Brazil for 40 years and who lives that journey between southern Brazil and Germany.... He finds himself a foreigner in his own home (Tiburi, our translation).

In this condition of expatriation, Tiburi comments that what saves her is precisely her work:

Today I think that what saves me, what makes me not get depressed, very sad, very melancholic, evidently - like anyone in a situation like this, with the losses and mourning that we do in life... I think what saves me is that I write, write, and write. Be it an essay, be it a novel, I'm always working on something. [...] I think I'm fine because I write (Tiburi, our translation).

The condition Marcia Tiburi is facing leads, according to her history, to an important dimension to think about the workers in political exile, or desterro (which is the expression she uses). This dimension refers to the centrality of work: for (re)organization, maintenance, and balance of life. Even though it was work (work engaged in political action, whether as a writer, professor, activist, or as a candidate for the government of Rio de Janeiro), an element (among others) that triggered the attacks she experienced, it was this same work that Tiburi claims to keep her well-being (albeit in the fragile conditions surrounding the lives of expatriates).

The discussion on the importance of work has been the subject of several studies for a long time. However, it is necessary to return to this debate to think about the issue of political exile. Clot (2006) states that work is not an activity among so many others; it is different because of the centrality it occupies in the subject's life, having a psychological function. Work is configured as one of the main dimensions of human life, as it interferes with the individual's insertion in society, limits the spaces of social mobility, and appears as one of the factors that constitute people's identity. Viegas (1989) highlights work throughout the person's development and actualization, i.e., to build oneself as a being, as an individual. In this perspective, the work means more than an occupation or an act of serving; it also provides opportunities for the development and fulfillment of an individual's life.

\footnotetext{
${ }^{11}$ Tiburi, M. (2016). Uma fuga perfeita é sem volta. Rio de Janeiro, RJ: Record.
} 
[...] the more the human puts themselves in the world, the more inner content they acquire. And that is precisely the meaning of work when it comes to life. Work is the human way of living up to life; it is the human way of producing, not merely creating reified objects, but in creating meanings. [...] work adds what I am to what I am not, adds what I am not to what I am. It gives a virtual dimension to my being (Viegas, 1989, pp. 10-11, our translation).

Regarding the psychological function of work, Dejours (1996) reinforces its importance concretely enabling sublimation. Sublimation is a process related to the object libido and consists of the instinct moving toward a different purpose and away from the original sexual satisfaction. Sublimation corresponds to the process that channels libidinal impulses to a socially useful and acceptable attitude; it can substitute the immediate objective for others that do not have a sexual nature, and that may be more highly valued (Freud, 2006a, 2006b). Freud (2006c) highlights that sublimation acts as a technique to ward off suffering, as it allows libido shifts, reorienting instinctual goals in ways that elude the frustration of the external world. In this way, "one gets the maximum when they can sufficiently intensify the production of pleasure from the sources of psychic and intellectual work" (Freud, 2006c, p. 87, our translation). Although it is not of interest in this work to go deeper into the psychoanalytic concept, it is important to stress here the productive and constructive path that Tiburi's work represents to her in her current life.

Dejours $(1996,2008)$ focuses on the possibilities of suffering and pleasure through activity, through the various possible processes of subjectification of the human being's relationship with work. To understand this dynamic, it is necessary to understand the work in its interiority and subjectivity (Freitas, 2000). According to the author, the work can be the stage of repetitions linked to past experiences, related to a chain of personal meanings, in a movement that is often unconscious. Thus, a past representation is not abolished, but "displaced" and remains active. Past situations are reframed in the present moment, and the subject can repeat their history in order to respond to a current situation. Freitas also points out that organizations are places of transference, where individuals can experience new and genuine relationships. However, they can also re-update their affective repertoire, rescuing motivations that are supported by reminiscences of past constructions.

In this process of 'destination' of original experiences and sufferings, Dejour's terminology establishes two ways in which work can be configured. First, as a form of instituting pathological suffering (the "suffering" path), which consists of the exact and sterile repetition of essential issues. The second is through production/creation of creative suffering (the "pleasure" path), in which sublimation stands out. Such a path represents the possibility of reframing work as a successful possibility between the individual content of the subject and the collective of work, as a condition of reconciliation between the unconscious and the production goals. In the context of the history presented and according to the experiences reported, it is striking the productive dimension of the work, particularly Marcia Tiburi's intellectual and creative work.

Going back to the history, Tiburi said that she is not formally exiled because, in Brazil, there is no such legal condition and that she did not apply for political asylum either, as she is an Italian citizen. However, she says that, if necessary, she is prepared to seek such status. She would love to go back to Brazil but back to a truly democratic country.

I have no reason to go back to Brazil ... It's better for me to stay here doing my thing than going back to Brazil and have to hide from the maniacs that run after me. Also, because we need to work ... Here I will continue to work, building my life, I cannot do that there, I would have to live in hiding, clandestine, always being careful (Tiburi, our translation).

Tiburi's comments highlighted another dimension of productive and constructive forms of obtaining pleasure from the activity (the question of public space). For Dejours (1996), obtaining pleasure and mental health from the activity is possible, among other things, by the establishment of a space of the word to the public space. This process consists of existing in and through work the possibility of the word, of the authentic expression of being, of elaboration, of resignification that will then occur in the public spaces of work activity. In the words of Dejours (1996, p. 171, our translation), "to summarize this focus on creative suffering, it would be possible to say that the transformation of suffering into creativity goes through a public space in the company. In return, whenever the public space tends to close, creativity will be threatened," and pathogenic suffering will be established.

The space of word allows subjects to transform suffering into the initiative and creative elaboration. Dejours considers this space of word 'public space.' After all, the idea of a space of word means the possibility of collective discussion, the intelligibility of behaviors. It is through the space of the word that knowledge about real work emerges. Until then, this knowledge was 
hidden by suffering and defense against suffering. Elements such as transparency, trust, and solidarity, are essential in the conduction of this space. They will operate in the construction of recognition and affiliation spaces, which are opposed to individualism and are consistent with the construction of the collective of work. This discussion refers to a condition that is different from the technique. It is the ethical condition, which is necessary - although not sufficient - for the establishment of intersubjective relationships among workers that allow them to build collective defenses against suffering and to give them the possibility of meaning in 'creative suffering.' The public space of work also consists of the elaboration of the psychological word to the political word (Karam, 2003). The author clarifies the need to recognize not only the centrality of work for the human being but its role for mental health through the promotion of citizenship.

In the case of Tiburi and the situation of exile, this reflection is extremely important. After all, it is precisely because of the suppression of the word (among other impossibilities of existing in her homeland) that led to her departure. The violence directed at Tiburi refers to an attempt to annihilate her physical, psychological, and social existence; all of these dimensions are marked by the importance of the word. In this context, exile is a condition of resistance and existence, so that life, and the word as life, can continue.

The public space of the word described by Dejours also leads to reflect on the necessary links of genuine solidarity that allow its existence. In the current context of Brazil, as described by Tiburi, there is a flagrant weakness of the ties of solidarity (which can be attributed to the individualistic dimension of a fascist project of society). In this context, there are even more obstacles toward the existence of public spaces of the word, obstacles toward the very existence itself. In situations in which solidarity and the notion of collectivity are weak, it is possible to observe a situation of abandonment.

Abandonment is a feeling that Tiburi uses to reflect on exile, as presented in her narrative. Abandonment due to the perception of lack of solidarity in the country, abandonment due to the condition of expatriation. It is through work and its psychological function, that Marcia Tiburi elaborates and transposes this feeling, and remains in resistance and existence, of body and word, in the country of exile. It is through this path that Tiburi continues to exist in spite of the exile, the refuge, the need for forced departure from her homeland because of the violence established in the Brazilian political and social scenario.

Anyway, then, I think desterro is the appropriate term. [...] and then I left. Going back ... I don't think that's possible. I don't have a home in Brazil anymore, I don't have a job in Brazil [...] I am too sad... and I don't see how I can collaborate there today. I think that if I went back to engage in a political campaign, I would be attacked again, I imagine that, if I was launching my books [...] I would receive hate messages regularly. [...] That's how I perceive life I would live.

That is how I understand what happened. But I think I still don't understand many things (Tiburi, our translation).

\section{TO WORK, TO EXIST, TO RESIST}

I'm strong, am I not? We are strong, aren't we? ... We have to be. Whoever survives patriarchy is capable of anything. We can handle it. We can handle everything. The problem is that there are people who do not survive. Look at Marielle ... look at female victims of domestic violence, feminicide ... look at the bizarre political violence that exists today. And so much violence against women ... and this ideological war came from these crazy people who invented the expression gender ideology, things like that. Look at these fascists in action, producing and building hate speech all the time. But we will continue, we will continue to fight (Tiburi, our translation).

In the light of a further singular perspective of analysis, considering Tiburi's history, the sublimation possibilities that work offers and its positive value stand out. Tiburi tells about it, especially when highlighting about her writing activity and how it has been crucial at this point in her life: "the more I think about it, the more I realize what saves me is that I write, write and write" (Tiburi). The work itself is an aspect that she highlights extraordinarily in her account. Obtaining concrete possibilities of sublimation through activity is a fundamental point for obtaining pleasure and health, elaborating the unique content of the original suffering and its transformation into content, which is productive for the subject. It is an elaboration 
process of one's being, which is notable in Tiburi's history (writing oeuvres with the theme of exile, as aforementioned in the previous section of this article, is a good example of the elaboration process that work itself, especially lifework and artwork, makes it possible).

In the matter of the most singular processes of subjective elaboration of an exile situation, the reflections of Indursky and Conte (2015) on psychic work in this condition, are resumed. It is a circumstance in which two traumas are combined: the traumas emerging from leaving the country of origin (violence, persecution, threats) that merge with those related to the exile condition itself (calling attention to the idea of "ex-he", from the French language "ex-il", and the exiled's identity uprooting). As for the identity losses related to exile, it was mentioned, as an example: the distance from markers and cultural parameters, family and affective references, adaptation processes to new sensory experiences, learning a new language, lack of space notion, among other conditions that are connected to a geo/psychic/social uprooting.

In respect to the exile complexities, it is also worth mentioning the vicissitudes of the "choice" to go into exile. Indursky and Conte (2015), highlight how this is configured as an option between one's own life or one's motherland, and they resort to the robbery metaphor as support for this comprehension:

Your money or your life? - the threatening approach that a thief imposes when the disagreeable decision to choose our destiny resonates in an instigating form, if juxtaposed with the decision to flee. When choosing the money, that is, staying in their motherland, the subject is left without both. If the subject chooses life, then he/she is separated from what engenders the decision - whether the money or the motherland (Indursky \& Conte, 2015, p. 276, our translation).

Tiburi's history (combined with theoretical reflections) points out how, given the situation of trauma inherent in exile, the work stands out as a guiding and structuring axis. Considering these comprehension axes, it is reinforced how work activity becomes a possibility to structure the continuity of existence, one's own history and identity itself - a form of structuring that allows orientation and continuation of life itself. The identity losses related to geographic, psychological, and social distance from the country of origin meet in the host country's work dimension the opportunity for re (structuring) and contiguity.

The loss situations require the conception of new modes of existence. The lost references elaboration demand, from the subject in exile, processes of (re) invention and (re) construction; within Tiburi's history, the work jumps out as a privileged manner to do so: a mode of restructuring herself and not breaking-up with her origin and even with her motherland.

According to Tiburi's account, the work stands out equally, as a mode of existence and resistance, not only at the individual level but also in the broader context of political action. "Here, I will continue to work, building my life; I cannot do that there" (Tiburi, our translation); an excerpt of Tiburi's account recovered to emphasize yet another function of work in the context of exile. In addition to the possibilities of elaboration to exist and resist in the individual and singular dimension of the person's life-history, the work also allows the continuity of the subject's political action: precisely what is denied to them in the fascist context of the society. Thus, the exile makes possible the permanence and existence of work that is resistance and fight against fascism, which purges them. The expatriation becomes, in this sense, the possibility of remaining active in the struggle to transform and overcome this situation. Thus, it is accentuated, as already highlighted in the text, the condition of exile as a possibility for (re) establishing a public space, a space of free, authentic, resistant and political word.

The work can also mean the (re) establishment of solidarity bonds that have been weakened in the fascist context of the country of origin, according to Tiburi's account. In research carried out with Brazilian political exiled people at the time of the military dictatorship, Marques (2011), demonstrates that although there was an intention of isolation of the militant in exile, what happened at that time, both in exile experiences in Chile and France, contradicted this expectation, since a large number of these people transformed exile into an environment of political combat through solidarity networks. Considering the case of the recent exile of Brazilians, and according to Tiburi's history, it is already possible to point out the (re) occurrence of this possibility via work.

In this regard, as highlighted by Marques (2011), the motivations that make the subject not request the legal condition of political exiled in the destination country. However, this condition represents protection to the individual, such legal status prevents the person from manifesting themself politically, which is, in general, precisely the nature of work of people who 
are in this condition (be it an artist, an intellectual, a militant, a public servant, etc.). Thus, legally framing oneself as a political exiled means the interruption of one's work. It is potential for existence and resistance, as it was argued in this article, in addition to the discontinuance of the public space of word.

\section{FINAL THOUGHTS}

This section brings back some points concerning the reflections made throughout the article, proposing paths that may be relevant to continue this discussion.

Regarding the importance of the study, this discussion is necessary to think about the current Brazilian context. Political exile is a reality. Thus, together with academic research on exile, this article registers this phenomenon and its current path. Regarding this work as a record of the time and context, the research has some particularities that are worthwhile to highlight, such as the opportunity to develop the study and collect information (field research) in loco et tempore, that is, at the exact moment and place of Tiburi's exile. This is a significant condition of the study.

Regarding the dimension of work in a situation of political exile, Tiburi's history allows inferring the importance and centrality of work as a way for the exiled to (re)build themselves and continue their existence in all their capacities and health. After all, the condition of existence is precisely what is denied in terms of violence, threats, hostilities, aggressions. Thus, productive work and public space - possibilities contested in the country of origin - become the elements of resumption of existence, resistance, and life.

Because of the history reported by Tiburi, the work stands out as a fundamental element in her narrative. As for this research analysis, and regarding the literature, it was considered the different meanings that work can present to the exiled person. At the individual level, the work is as a form of (re) structuring oneself for those who experience geo/psychic/social uprooting processes and their consequent identity losses, in addition to the situation of double trauma, already mentioned; a form to continue one's existence, to resist, to (re) exist. Concomitantly, at the social level, the work is configured as a mode of political action, a form of continuing the effort for transformation, precisely what is prohibited in the fascist context of society; also, a primary form of existence, resistance, (re) existence. Further, there is also the possibility of rebuilding support and solidarity bonds that can result from work, in contrast to the perception of abandonment that permeates an exile condition.

The contributions of this research are also reinforced for the organizational field of investigation. One of them refers to the approach of the political exile occurrence in modern Brazil. This data itself warns the serious and problematic situation faced in the country in recent years. Combined with this fact, it was outlined in this article discussions about the context of the far-right rise to rule Brazil (what is called a contemporary neo-fascism), together with considerations about political exile reinforcing the originality and the need for this discussion to be made in the Management context. Although the reflection on work and expatriation are themes that are widely debated in the management sciences, making the issue of political exile visible, in the case of Brazilians, adds contemporary facts to this discussion.

Writing about the experience of an exiled person from the perspective of life-history research is also a contribution that the authors of this study consider valuable, both for the presentation of the article's subject matter as well as a demonstration of a fruitful methodological possibility for investigations related to refugees and displaced people in the workplace. Thus, approaching this issue from the subject's point of view and from the suffering of those who live in such a situation in their own existence refers to sensitivities and competencies that are highly needed to scholars in this field of work.

Although studies about the senses and centrality of work are numerous and have been present in the field of Management for a long time, it is always necessary to revisit this discussion due to its importance and, especially, when the new phenomena appear or past ones reappear with new shapes, which is the case of exile. In the present article, it was also highlighted the recall and interdisciplinary dialogue between psychoanalytic and psychosociological literature, with theoretical references in the field of political science about work, political exile and fascism. 
Regarding fascism, Tiburi's history is a relevant case to reflect on neo-fascism today and the consequences of this situation. As for fascism, the case leads the discussion to another dimension that needs further studies in the future: the patriarchal facet of authoritarian frameworks. On this point, she warns:

"Patriarchy is a system of oppression based on male privilege, on the cult of the male. It is the gender version of capitalism. Capitalism is for capital, just as patriarchy is for gender. What is fascism in the middle of it all? Fascism is an observation of the hatred of the masses to deny the other. Fascism is paranoid. It is an organized system that depends on all forms of prejudice. It depends on misogyny; it depends on homophobia; it depends on racism ... [...] sometimes fascism gives space to women, as long as they are sexist. If they are collaborationists" (Tiburi, our translation).

In addition to the patriarchal aegis of such authoritarian relations, it is possible to consider other elements, also raised by Tiburi's history. Within the Management field, this study still reflects on contemporary social characteristics that can engender a neo-fascist condition of society, such as: the weakening of unions and organizations of civil society, individual isolation, unemployment, and losses in labor rights, the phenomenon of "being one's own company," among other processes of loss of collectivity and solidarity (elements Tiburi stresses in her experiences). Such processes provide for a political and social uprooting of people, based on the logic and domination of financial capitalism in its current stage. "This isolated and helpless individual is plagued by aggressiveness that they do not understand and, thus, they either direct the anger felt for their poverty and deprivation against themselves, or they channel this anger against scapegoats built for this purpose" (Souza, 2019 , p. 253, our translation). Finally, these are questions for future studies concerning the complexity of understanding this phenomenon and the context in which the history presented here emerges. Finally, and above all, it is highlighted the intention of this research, which is to contribute with elaborations about exile and the situation in Brazil today, based on the history presented and the reflections it inspired.

Finally, throughout this research, it was intended that the discussion presented regarding work in the context of Brazilians in political exile would be contributory to the dossier under discussion, whose focus is the experience of refugees and displaced people in various circumstances. Tiburi's history and reflections on political exile and the neo-fascist context disclose how work is a central activity for people's existence and resistance in such a situation. Furthermore, reverberating this discussion in the Management field also suggests a necessary action to reflect on this reality and the manners in which organizations, leaders and policymakers can aid people in such conditions to find work, keep their jobs and positive results, among others, as recommended in the objectives of the present call for papers.

\section{ACKNOWLEDGEMENTS}

The authors would like to thank Marcia Tiburi for her availability and confidence in recounting us her life history, which honors us profoundly; Cadernos EBAPE.BR's peer reviewers for their valuable contributions to the article; Escola de Administração da Universidade Federal do Rio Grande do Sul (EA/UFRGS) for supporting the post doctoral; Research group Pesquisa Histórica em Administração da Pontifícia Universidade Católica do Rio de Janeiro (IAG/PUC-Rio); Programa de Pós-Graduação em Administração de Empresas da Pontifícia Universidade Católica do Rio de Janeiro (IAG/PUC-Rio); Dominique Lhuilier and the Centre de Recherche sur le Travail et le Développement du Conservatoire National des Arts et Métiers (CNAM-Paris). This research was supported by the Conselho Nacional de Desenvolvimento da Ciência e Tecnologia - Brasil (CNPq) under grant no. 308191/2019-6. 


\section{REFERENCES}

Arfuch, L. (2010). O espaço biográfico: dilemas da subjetividade contemporânea. Rio de janeiro, RJ: EdUERJ.

Barros, V. A., \& Lopes, F. T. (2014). Considerações sobre a pesquisa em história de vida. In E. M. Souza (Org.), Metodologias e analíticas qualitativas em pesquisa organizacional: uma abordagem teóricoconceitual. Vitória, ES: EDUFES.

Barros, V. A., \& Silva, L. R. (2002). A Pesquisa em História de Vida. In I. B. Goulart, \& A. A. L. Santos (Eds.), Psicologia organizacional e do trabalho: teoria, pesquisa e temas correlatos. São Paulo, SP: Casa do Psicólogo.

Bosi, E. (2003). O tempo vivo da memória: ensaios de psicologia social. São Paulo, SP: Ateliê Editorial.

Buarque, C., \& Toquinho. (1971). Samba de Orly. Rio de Janeiro, RJ: Philips/Phonogram.

Clot, Y. (2006). A função psicológica do trabalho. Petrópolis, RJ: Vozes.

Decker, S., Hassard, J., \& Rowlinson, M. (2020). Rethinking history and memory in organization studies: The case for historiographical reflexivity. Human Relations. Retrieved from https://doi. org/10.1177/0018726720927443

Dejours, C. (1996). Uma nova visão do sofrimento humano nas organizações. In J. Chanlat (Coord.), O indivíduo na organização: dimensões esquecidas. São Paulo, SP: Atlas.

Dejours, C. (2008). Addendum da psicopatologia à psicodinâmica do trabalho. In S. Lancman, \& L. I. Sznelwar (Orgs.), Christophe Dejours: da psicopatologia à psicodinâmica do trabalho. Brasília, DF: Paralelo 15.

Ferrarotti, F. (2007). Las historias de vida como método. Convergencia. Revista de Ciencias Sociales, 14(44), 15-40.

Ferreira, M. L. M., \& Serres, J. C. P. (2018). Museus e Narrativas do Sofrimento: Reflexões sobre os limites do dizível. In L. Bauer, \& V. T. Borges (Eds.), História oral e patrimônio cultural: potencialidades e transformações. São Paulo, SP: Letra e Voz.

Folha de S. Paulo. (2018, novembro 06). SBT ressuscita e mata 'Brasil, ame-o ou deixe-o' em vinheta relâmpago. Retrieved from https:// www1.folha.uol.com.br/ilustrada/2018/11/sbt-ressuscita-brasilame-o-ou-deixo-o-em-nova-vinheta.shtml

Freitas, M. E. (2000). A questão do imaginário e a fronteira entre a cultura organizacional e a psicanálise. In F. C. P. Motta, \& M. E. Freitas (Orgs.), Vida psíquica e organização. Rio de Janeiro, RJ: Editora FGV.

Freud, S. (2006a). Sobre o narcisismo: uma introdução. In S. Freud (Ed.), Edição standard brasileira das obras psicológicas completas de Sigmund Freud: v. XIV (Trabalho original publicado em 1914). Rio de Janeiro, RJ: Editora Imago.

Freud, S. (2006b). Leonardo da Vinci e uma lembrança de sua infância. In S. Freud (Ed.), Edição standard brasileira das obras psicológicas completas de Sigmund Freud: v. XVI (Trabalho original publicado em 1910). Rio de Janeiro, RJ: Editora Imago.

Freud, S. (2006c). O mal-estar na civilização. In S. Freud (Ed.), Edição standard brasileira das obras psicológicas completas de Sigmund Freud: v. XXI (Trabalho original publicado em 1930). Rio de Janeiro, RJ: Editora Imago.
Godfrey, P. C., Hassard, J., O'Connor, E. S., Rowlinson, M., \& Ruef, M. (2016). What is organizational history? Toward a creative synthesis of history and organization studies. Academy of Management Review, 41(4), 590-608.

González Rey, F. (2005). Pesquisa qualitativa e subjetividade: os processos de construção da informação. São Paulo, SP: Pioneira Thomson Learning.

Habermas, J. (2009). A lógica das ciências sociais. Petrópolis, RJ: Editora Vozes.

Indursky, A. C., \& Conte, B. S. (2015). Trabalho psíquico do exílio: o corpo à prova da transição. Ágora, 18(2), 273-288.

Karam, H. (2003). O Sujeito entre a alcoolização e a cidadania: perspectiva clínica do trabalho. Revista de Psiquiatria do Rio Grande do Sul, 25(3), 468-474.

Laville, C., \& Dionne, J. (1999). A Construção do Saber. Manual de Metodologia da Pesquisa em Ciências Humanas. Porto Alegre, RS: Editora UFMG.

Lubinski, C. (2018). From 'History as Told' to 'History as Experienced': Contextualizing the Uses of the Past. Organization Studies, 39(2), 1785-1809.

Marques, T. C. S. (2011). Militância política e solidariedade transnacionais: a trajetória política dos exilados brasileiros no Chile e na França (1968-1979) (Doctoral Dissertation). Universidade Federal do Rio Grande do Sul, Porto Alegre, RS.

Marques, T. C. S. (2017). O Exílio e as Transformações de Repertórios de Ação Coletiva: A Esquerda Brasileira no Chile e na França (19681978). DADOS - Revista de Ciências Sociais, 60(1), 239-279.

Phillips, D. (2019, julho 11). New generation of political exiles leave Bolsonaro's Brazil 'to stay alive'. The Guardian. Retrieved from https://www.theguardian.com/world/2019/jul/11/ brazil-political-exiles-bolsonaro

Pinheiro-Machado, R. (2019, agosto 06). Fuga de cérebros e autoexílio: governo Bolsonaro reacende o trauma da ditadura. Ascensão da extrema direita e crise econômica levam à debandada de pesquisadores e ativistas desde a ditadura. Fuga de cérebros é fracasso de um país. The Intercept Brasil. Retrieved from https://theintercept. com/2019/08/05/fuga-de-cerebros-e-autoexilio-governo-bolsonaroreacende-o-trauma-da-ditadura/

Ricoeur, P. (1983). Temps et récit. Paris, France: Seuil.

Roniger, L. (2010). Exílio Massivo, Inclusão e Exclusão Política no Século XX. DADOS - Revista de Ciências Sociais, 53(1), 91-123.

Schultz, M., \& Hernes, T. (2013). A Temporal Perspective on Organizational Identity. Organization Science, 24(1), 1-21.

Souza, J. (2019). A elite do atraso. Rio de Janeiro, RJ: Estação Brasil.

Stanley, J. (2019). Como funciona o fascismo: a política do "nós" e "eles". Porto Alegre, RS: L\&PM.

Tiburi, M. (2018). Como conversar com um fascista. Reflexões sobre o cotidiano autoritário brasileiro. Rio de Janeiro, RJ: Record. 
Viegas, S. (1989). Trabalho e vida. In Anais da Conferência Para os Profissionais do Centro de Reabilitação Profissional do INPS, Belo Horizonte, MG.

Villen, P. (2018, novembro 09). Brasil, país de expulsão? Desemprego e emigração no Brasil. ComCiência. Revista Eletrônica de Jornalismo Científico. Retrieved from http://www.comciencia.br/ brasil-pais-de-expulsao-desemprego-e-emigracao-no-brasil/
Wadhwani, D. D., Suddaby, R., Mordhorst, M., \& Popp, A. (2018). History as Organizing: Uses of the Past in Organization Studies. Organization Studies, 39(12), 1663-1683.

Wanderley, S., \& Barros, A. (2018). Decoloniality, geopolitics of knowledge and historic turn: towards a Latin American agenda, Management \& Organizational History, 14(1), 79-97.

Ph.D. in Administration from the Federal University of Minas Gerais (UFMG); Professor at the School of Administration at the Federal University of Rio Grande do Sul (EA/UFRGS). E-mail: fernanda.tarabal@ufrgs.br

Alessandra de Sá Mello da Costa ORCID: https://orcid.org/0000-0003-3207-2888

Ph.D. in Administration from Fundação Getulio Vargas (FGV EBAPE); Professor at the Pontifical Catholic University of Rio de Janeiro (IAG/PUC-Rio).

E-mail: alessandra.costa@iag.puc-rio.br 